Publisher homepage: www.universepg.com, ISSN: 2663-6913 (Online) \& 2663-6905 (Print)

https://doi.org/10.34104/ajpab.021.085097

American Journal of Pure and Applied Biosciences Journal homepage: www. universepg.com/journal/ajpab

\title{
More to Explore; The Mesenchymal Stem Cells (MSCs) Major Tissue Sources, Known Surface Markers and Its Immunomodulation properties
}

\author{
Kanwal Abbasi $^{1}$ *, Samina Iqbal ${ }^{1}$, Saeeda Bano ${ }^{1}$, Kausar Siddiqui $^{1}$ and Lovely Muthiah ${ }^{2}$ \\ ${ }^{1}$ Pharmaceutical Research Center, Pakistan Council of Scientific and Industrial Research (PCSIR), Laboratories Complex, \\ Karachi-75280, Pakistan; ${ }^{2}$ Specialist Prosthodontist, Family Care Medical Center, Ras Al Khaimah, UAE. \\ *Correspondence: kanwalabbasi@ yahoo.com (Dr. Kanwal Abbasi, Senior Scientific Officer, Pharmaceutical research center, \\ Pakistan Council of Scientific and Industrial Research (PCSIR), Karachi, Pakistan).
}

\begin{abstract}
Mesenchymal stem cells (MSCs) are currently available for a range of applications and have become a good material for regenerative medicine, tissue engineering, and disease therapy. MSCs are self-renewing, multipotent progenitor cells with multilineage potential to differentiate into cell types of mesodermal origin, such as adipocytes, osteocytes, and chondrocytes and exert potent immunosuppressive potentials. In the present review, we highlight the currently reported variations in the differentiation potential of MSCs from different tissue sources, the minimal criteria to define MSCs from various tissue environments and provide a detailed description of MSCs surface markers. Furthermore, MSCs immunomodulatory features secrete cytokines and immune receptors which regulate the microenvironment in the host tissue also revisits in detail. We propose that there are likely more sources of MSCs waiting to be discovered. We need to Standardize MSCs characterization by selecting markers for isolation, cellular and molecular mechanisms involved in MSCmediated immune modulation, and other functionalities of MSCs should be characterized prior to use in clinical applications.
\end{abstract}

Keywords: Mesenchymal stem cells (MSCs), Tissue sources, Surface marker, Cytokines and Immunomodulation.

\section{INTRODUCTION:}

Stem cells represent a novel cell type in the body. Stem cells have two features: the ability to differentiate along different lineages and the ability to self-renew and maintain tissue homeostasis. Stem cells can be multiplied in large Stem cells are broadly classified based on their source into embryonic (hESCs) and adult (ASCs) stem cells. Bhartiya, (2013) Embryonic stem cells are pluripotent in nature and can be differentiated into 200 odd cell types where as the adult stem cells are isolated from adult body tissues and are multi-to unipotent in nature (Thomson et al., 1998). MSCs are adult stem cells which can be isolated from human and animal

UniversePG I www.universepg.com sources with the capacity to differentiate into mesodermal lineage. MSCs and their multiline age were first found by Friedenstein via studies on the mouse bone marrow in the 1960s (Friedenstein et al., 1987; Friedenstein et al., 1976; Friedenstein, 1966).

The multiline age differentiation potential of adult human MSCs from bone marrow was described by Pittenger and group. They have been isolated from almost all tissues including per vascular area (Pittenger et al., 1999). In view of many studies till now, neither single definition nor a quantitative assay to help in the identification of MSCs in mixed population of cells is available; some biomarkers are available for identi- 
fication of human MSC (hMSC). In 2006 a set of markers and cell characteristics has been proposed by the International Society for Cellular Therapy has proposed minimum criteria to define MSCs as these cells (a) should exhibits plastic adherence; (b) possess specific set of cell surface markers, i.e. cluster of differentiation CD73, D90, CD105 and lack expression of CD14, CD34, CD45 and human leucocyte antigen-DR (HLA$\mathrm{DR})$; and (c) have the ability to differentiate in-vitro into adipocyte, chondrocyte and osteoblast (Crisan et $a l .$, 2008). The availability and culturally expandable in vitro with special genomic stability and less ethical issues, marking these incredible cells importance in cell regenerative therapy and medicine (Dominici et al., 2006; Ullah et al., 2015). The resent study is the concise review article to gather available the information about stem cell sources, identification makers, Paracrine secretion, Immunomodulation by MSCs and their importance in regenerative therapies.
Human Mesenchymal Stem Cell (HMSC) Sources:

The bone marrow (BM) has been the prevailing source of MSCs in humans (Mushahary et al., 2018). However, while BM is a rich source of hematopoietic stem cells, it constitutes only a rare MSC population ( $\mathrm{Li}$ et al., 2016) BM-derived MSC (bmMSC) supply is the painful harvesting procedure marking their application in research and in the clinical setting limited. Over time, a number of other tissues have been identified as alternative sources for hMSC. Today, MSC can be isolated from multiple tissues (Ullah et al., 2015). The human MSC (hMSC) properties can vary greatly depending on multiple parameters including tissue source, isolation method and medium composition and several studies mentioned variations in the differentiation potential of MSC from different tissue sources. Table 1 summaries some of the currently used tissue sources and the respective confirmed differentiation potentials.

Table 1: Summary of hMSCs tissue sources and In-vitro differentiation potentials.

\begin{tabular}{|c|c|c|c|}
\hline SN & Source & In vitro differentiation & References \\
\hline \multirow{5}{*}{1.} & \multirow{5}{*}{ Bone Marrow } & Osteocytes, chondrocytes, adipocytes & $\begin{array}{c}\text { (Li et al., 2016; Mamidi et al., 2012; Otsuru et al., } \\
\text { 2013; Ranera et al., 2013) }\end{array}$ \\
\hline & & Hepatocytes & (Zhang et al., 2011) \\
\hline & & Cardiomyocytes & (Stock et al., 2014) \\
\hline & & Pancreatic cells & (Xu et al., 2004; Tang et al., 2012; Gabr et al., 2013) \\
\hline & & Neuronal cells & (Phadnis et al., 2011; Barzilay et al., 2009) \\
\hline \multirow{5}{*}{2.} & \multirow{5}{*}{ Adipose Tissue } & Osteocytes, chondrocytes, adipocytes & $\begin{array}{l}\text { (Barzilay et al., 2009; Wilkins et al., 2009; } \\
\text { Pendleton } \text { et al., 2013) }\end{array}$ \\
\hline & & Hepatocytes & (Wagner et al., 2005) \\
\hline & & Cardiomyocytes & (Baglioni et al., 2009) \\
\hline & & Pancreatic cells & (Wang et al., 2014) \\
\hline & & Neuronal cells & (Choi et al., 2010; Timper et al., 2006) \\
\hline \multirow{5}{*}{3.} & \multirow{5}{*}{$\begin{array}{l}\text { Umibical cord, } \\
\text { Umibical cord } \\
\text { blood }\end{array}$} & Osteocytes, chondrocytes, adipocytes & (Kang et al., 2003; Miao et al., 2006) \\
\hline & & Hepatocytes & (La Rocca et al., 2009; Baek et al., 2014) \\
\hline & & Endothelial like cell & (Wilkins et al., 2009) \\
\hline & & Pancreatic cells & (Hang et al., 2014) \\
\hline & & Neuronal cells & (An et al., 2014) \\
\hline \multirow{4}{*}{4.} & \multirow{4}{*}{ Dental Tissue } & Osteocytes, chondrocytes, adipocytes & (Prabakar et al., 2012; Zhao et al., 2014) \\
\hline & & Pancreatic cells & (Huang et al., 2009; Hilkens et al., 2013) \\
\hline & & Neuronal cells & (Govindasamy et al., 2011; Kanafi et al., 2013) \\
\hline & & Melanocytes & (Zhao et al., 2014) \\
\hline \multirow{2}{*}{5.} & \multirow{2}{*}{ Amniotic fluid } & Chondrocytes, adipocytes & (Völlner et al., 2009; Wang et al., 2010) \\
\hline & & Neuronal cells & (In't Anker et al., 2003) \\
\hline \multirow{2}{*}{6.} & \multirow{2}{*}{$\begin{array}{l}\text { Skin- and foreskin- } \\
\text { derived MSCs }\end{array}$} & Osteocytes, chondrocytes, adipocytes & (Tsai et al., 2004; CaiH et al., 2010) \\
\hline & & Myocytes & (Tsai et al., 2004) \\
\hline \multirow{3}{*}{7.} & \multirow{3}{*}{$\begin{array}{l}\text { Limb bud-derived } \\
\text { MSCs }\end{array}$} & Osteocytes, adipocytes & (Bartsch et al., 2005) \\
\hline & & Hepatocytes & (Bartsch et al., 2005) \\
\hline & & Neuronal cells & (Bartsch et al., 2005) \\
\hline \multirow{2}{*}{8.} & \multirow{2}{*}{ Placenta } & Adipocytes, Osteocytes & (Riekstina et al., 2008; Jiao et al., 2012) \\
\hline & & Endothelial like cell & (Jiao et al., 2012) \\
\hline
\end{tabular}


Abbasi et al., / American Journal of Pure and Applied Biosciences, 3(4), 85-97, 2021

\begin{tabular}{|c|c|c|c|}
\hline & & Neuronal cells & (Jiao et al., 2012) \\
\hline \multirow{3}{*}{9.} & \multirow{2}{*}{ Salivary gland } & Osteocytes, chondrocytes, adipocytes & $\begin{array}{c}\text { (Raynaud } \text { et al., 2012; Rotter } \text { et al., 2008; Sato } \text { et al., } \\
\text { 2007; Baek } \text { et al., 2014) }\end{array}$ \\
\cline { 3 - 4 } & & Pancreatic cells & (Sato et al., 2007; Baek et al., 2014) \\
\hline 10. & Synovial fluid & Osteocytes, chondrocytes, adipocytes & (Sui et al., 2020; Morito et al., 2008) \\
\hline \multirow{3}{*}{11.} & \multirow{2}{*}{ Wharton's jelly } & Osteocytes, chondrocytes, adipocytes & $\begin{array}{c}\text { (Hatakeyama } \text { et al., 2017; Hou } \text { et al., 2009; } \\
\text { Salehinejad } \text { et al., 2012; Christodoulou } \text { et al., 2013) }\end{array}$ \\
\cline { 3 - 4 } & & Hepatocytes & (Yoon et al., 2013) \\
\cline { 3 - 4 } & & Neuronal cells & (Anzalone et al., 2010) \\
\cline { 3 - 4 }
\end{tabular}

Markers for MSC Identification and Verification:

The International Society for Cellular Therapy (ISCT) published the minimal criteria for defining MSCs in 2006. The ISCT proposed positive and negative markers that enabled researchers to distinguish MSCs from other cells in the bone- marrow compartment. The negative markers were selected to include surface antigens that are expressed by hematopoietic cells, while the positive markers were selected to include surface antigens that are absent from most hematopoietic cells. It is well established that cultured colonies of MSCs express CD105, CD73, and CD90, but do not express CD45, CD34, CD14 or CD11b, CD19, and HLA-DR (Datta et al., 2011; Karystinou et al., 2009) Table 2. Some labeling strategies have also been used to successfully isolate MSCs enriched for markers such as STRO-1 (Saeedi et al., 2019; Gronthos et al., 2003; Kuroda et al., 2010; Psaltis et al., 2010) CD146 (Bensidhoum et al., 2004; Covas et al., 2008), SSEA-4 (da Silva Meirelles et al., 2015; Gang et al., 2007), CD271 (NGFR) (Battula et al., 2008; Vaculik et al., 2012) antigen 1 (MSCA-1). ISCT acknowledges that the criteria must be met with some flexibility, particularly as they relate to expression of the negative mar- ker, HLA Class II. Specifically, HLA Class II can be expressed by MSCs under certain conditions, such as cytokine stimulation. Therefore, cells that meet all other criteria, but are also positive for HLA Class II, can be designated as MSCs if an adjective is used to indicate that the cells were stimulated. According to the ISCT, CD34 is a negative marker of MSCs. However, some reports suggest that the CD34 negative status is an artifact of cell culture condition (Pilbauerová et al., 2019). In fact, several groups have shown that MSCs isolated from adipose tissue express CD34 at the time of isolation but lose expression while in culture (Lin et al., 2012; Quirici et al., 2010). Expression of CD34 by MSCs is also supported by the fact that the STRO-1 antibody (Clone STRO-1), which is commonly used to identify MSCs, was developed using CD34+bone marrow as the immunogen (Pachón-Peña et al., 2011). The debate over the use of CD34 as a negative marker raises the possibility that markers may vary depending on the MSC tissue source (Kim \& Cho, 2013). For specific immunophenotypic patterns, the variety of tissue sources of peripheral stem cells that could be isolated by their lineage-specific surface markers are summarized in Table 3.

Table 2: Minimal criteria of mesenchymal stem cells.

\begin{tabular}{|c|c|c|c|}
\hline Surface markers & $\begin{array}{l}\text { Differentiation } \\
\text { potential }\end{array}$ & & $\begin{array}{l}\text { Other } \\
\text { characteristics }\end{array}$ \\
\hline Positive Marker & & Biological Role & \\
\hline CD73+ & Osteogenic & Catalyzes the conversion of AMP to bioactive adenosine & Adherence to plastic \\
\hline CD90+ & Adipogenic & Wound repair, cell-cell and cell-matrix interactions & $\begin{array}{l}\text { Spindle-shape } \\
\text { morphology }\end{array}$ \\
\hline CD105+ & Chondrogenic & $\begin{array}{c}\text { Vascular homeostasis; modulates TGF-beta functions via } \\
\text { interaction with TGF-beta RI and TGF-beta RI }\end{array}$ & \\
\hline Negative Marker & & Used to Exclude & \\
\hline CD34- & & Primitive hematopoietic cells and endothelial cells & \\
\hline CD45- & & Leukocytes & \\
\hline CD11b- & & Monocytes and macrophages & \\
\hline CD14- & & Monocytes and macrophages & \\
\hline CD19- & & B cells & \\
\hline CD79a- & & B Cells & \\
\hline HLA-DR- & & B cells, T cells, monocytes, macrophages & \\
\hline
\end{tabular}


Table 3: Surface Marker Expression Profiles of Main MSC Types.

\begin{tabular}{|c|c|c|c|}
\hline SN & MSCs & CD Marker Expression & Reference \\
\hline 1 & ADSCs & $\begin{array}{c}\text { CD9+, CD10+, CD13+, CD29+, CD44+, CD49D+, CD49E+, CD54+, } \\
\text { CD55+, CD71+, CD73+, CD90+, CD105+, CD106+, CD146+, CD166+, } \\
\text { STRO-1+ } \\
\text { CD11B }, \mathrm{CD}^{-}, \mathrm{CD}^{-}, \mathrm{CD} 31^{-}, \mathrm{CD} 45^{-}, \mathrm{CD}^{-} \mathrm{A}^{-}, \mathrm{CD} 133^{-}, \mathrm{CD}^{-}{ }^{-}, \mathrm{HLA}^{-} \mathrm{DR}^{-}\end{array}$ & $\begin{array}{l}\text { (Chan } \text { et al., 2014); } \\
\text { Vasiliki, 2016; Huang } \\
\text { et al., 2013) }\end{array}$ \\
\hline 2 & BMMSCs & $\begin{array}{c}\mathrm{CD} 13+, \mathrm{CD} 33+, \mathrm{CD} 44+, \mathrm{CD} 73+, \mathrm{CD} 90+, \mathrm{CD} 105+, \mathrm{CD} 166+, \mathrm{CD} 28+, \\
\text { HLA class I+ } \\
\mathrm{CD}^{-}, \mathrm{CD} 34^{-}, \mathrm{CD} 45^{-}\end{array}$ & $\begin{array}{c}\text { (Dominici } \text { et al., 2006; } \\
\text { Zuk, 2010; } \\
\text { Gauthaman } \text { et al., 2010) }\end{array}$ \\
\hline 3 & PDLSCs & STRO-1+, CD13+, CD29+, CD44+, CD59+, CD90+, CD105+ & $\begin{array}{l}\text { (Huang et al., 2009; } \\
\text { Boxall \& Jones 2012) }\end{array}$ \\
\hline 4 & TBMSCs & CD73+, STRO-1+, CD105+ & (Pérez-Silos et al., 2016) \\
\hline 5 & SMMSCs & CD44+, CD73+, CD90+, CD105+ & (Tuli et al., 2003) \\
\hline 6 & PMSCs & CD90+ & (Djouad et al., 2005) \\
\hline 7 & MMSCs & CD34+, CD117+, Sca1+ & $\begin{array}{l}\text { (Johnstone } \text { et al., 1998; } \\
\text { Jankowski } \text { et al., 2002) }\end{array}$ \\
\hline 8 & SSCs & $\begin{array}{l}\text { CD105+, CD90+, CD73+, CD29+, CD13+, CD44+, CD59+, VCAM-1+, } \\
\text { ICAM-1+, CD49+, CD166+, SH2+, SH4+, EGFR+, PDGFR } \alpha+, \text { CD271+, } \\
\text { Stro-1+, CD71+, CD133+, CD166+, Keratin-19+ } \\
\text { CD10-, CD11b-, CD14-, CD34-, CD49d- and HLA-DR- }\end{array}$ & $\begin{array}{l}\text { (Qu-Petersen } \text { et al., } \\
\text { 2002; Vishnubalaji } \text { et } \\
\text { al., 2012) }\end{array}$ \\
\hline 9 & WJ-MSCs & $\begin{array}{l}\text { CD13+, CD29+, CD44+, CD51+, CD73+, VCAM-1, CD166 } \\
\text { CD90+, CD105+, SH2, SH3, SSEA-1 }\end{array}$ & $\begin{array}{c}\text { (Orciani } \text { et al., 2010; } \\
\text { Gauthaman } \text { et al., 2010) }\end{array}$ \\
\hline 10 & $\begin{array}{c}\text { Hepatic } \\
\text { stem cells }\end{array}$ & EpCAM+, E-cadherin+, CD133+, CD29+ & (Yazdekhasti et al., 2018) \\
\hline 11 & $\begin{array}{l}\text { Peripheral } \\
\text { Blood MSC }\end{array}$ & $\begin{array}{c}\mathrm{CD}_{4} 4^{+}, \mathrm{CD}^{\mathrm{C}} 4^{+}, \mathrm{CD}^{-} 0^{+}, \mathrm{CD} 105^{+}(\mathrm{SH} 2), \mathrm{CD}^{\circ} 66^{+} \\
\mathrm{CD} 14^{-}, \mathrm{CD} 34^{-}, \mathrm{CD} 45^{-}, \mathrm{CD} 31^{-}\end{array}$ & (Kim \& Cho, 2013) \\
\hline 12 & DPSCs & 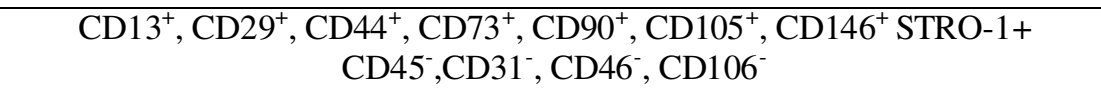 & $\begin{array}{l}\text { (Tosh \& Strain 2005; } \\
\text { Paduano et al., 2016) }\end{array}$ \\
\hline
\end{tabular}

Note: MSCs: mesenchymal stem cells; CD: cluster of differentiation; ADSCs: adipose-derived stem cells; BMMSCs: bone marrowderived mesenchymal stem cells; HLA: human leukocyte antigen; PDLSCs: periodontal ligament-derived stem cells; TBMSCs: trabecular bone-derived mesenchymal stem cells; SMMSCs: synovial membrane- derived mesenchymal stem cells; PMSCs: periosteum-derived mesenchymal stem cells; MMSCs: muscle-derived mesenchymal stem cells and satellite cells; Sca1: stem cell antigen 1; VCAM: vascular cell adhesion molecule; ICAM: inter-cellular adhesion molecule; SSCs: skin stem cells; SH2: CD105 antibody; SH4: CD73 antibody; EGFR: epidermal growth factor receptor; PDGFR $\alpha$ : platelet-derived growth factor receptor $\alpha$; WJ-MSCs: Wharton's jelly mesenchymal stem cells; SH3: CD73 antibody; EpCAM: epithelial cell adhesion molecule; DPSCs: dental pulp stem cells.

\section{Mesenchymal Stem Cell Markers Co-expression:}

The purity of MSCs can be increased by using more than one MSC marker for positive selection. As an example, a recent publication demonstrated that selection of mesenchymal stem cells using CD271/NGF R, CD90/Thy1, and CD106/VCAM-1 resulted in a highly clonogenic population of cells (Simmons \& TorokStorb, 1991). Specifically, the addition of CD106 as a marker for positive selection led to isolation of cells with five times greater clonogenic potential compared to the cells isolated with CD271/and CD90 alone. The degree of co expression of surface markers on MSCs also studied (Rasmusson et al., 2003). The cells subsets detected for the presence of MSCA-1/TNAP, CD271/NGF R and CD56/NCAM from whole cell population of Human BM-MNCs were analyzed and reported that the CD271 expression detected and CD56 UniversePG I www.universepg.com expression not detected cells expressed CD106 and CD146 whereas, CD271 and CD56 presences detected cells exclusively expressed CD166 (Mabuchi et al., 2013) CD271 and CD56 double positivity enriched SSEA-4 expression and MSCA-1 expression. The study conducted by Vaculik et al. (2012), explains the expression pattern of SSEA-4 in dermis was analogous to CD271. CD271 and SSEA-4 both co expressed with CD45 detected cells, in human dermis where as CD73 and CD105 are co expressed. The human dermis minor population of CD73 detected cells are not expressed CD90 (Battula et al., 2008). Dermis CD271 positive cells were also positive for CD73and CD105, whereas the majority of CD271 positive cells are CD90 negative (Battula et al., 2008). Several other studies have been performed recently aimed at achieving high-purity BM MSCs using a combination of CD271 and markers 
other than CD73, CD105, or CD90 (Pérez-Silos et al., 2016) for example, CD146 has attracted a lot of interest recently, by linking CD146 expression on MSCs with their pericyte topography and function (Battula et al., 2009; Pittenger et al., 1999). It was also reported that CD146 expression on CD271 positive MSCs correlates more with their in situ localization (Sacchetti et al., 2007). Maijenburg further reported that the distribution of CD271 and CD146 and subsets correlates with donor age. The main subset in pediatric and fetal BM was reported to be CD271 expression and CD146 expression, whereas the subset of CD271 expression and CD146 not expression detected population was dominant in adult marrow (Tormin et al., 2011). The endometrial MSC-like cells (eMSCs) can be purified on the basis of their co expression of two per vascular markers, CD140b/platelet-derived growth factor receptor $\beta$ (PDGFR $\beta$ ) and CD146 (Maijenburg et al., 2012). The first novel single marker, W5C5 for isolation of endometrial MSC-like cells (eMSCs) (Schwab \& Gargett et al., 2007; Masuda et al., 2012)

\section{Immunomodulatory Properties of MSCS:}

One of the main advantages of MSCs is their immunomodulatory properties. MSCs grown in vitro have the ability to interact and regulate the function of the majority of effectors cells involved in the processes of primary and acquired immune response. Due to low expression of MHC I and lack expression of MHC class II along with co-stimulatory molecules, like CD80, CD40 and CD86, MSCs are unable to bring substantial all reactivity and these features protects MSCs from natural killer (NK) cells lysis (Masuda et al., 2012).

Moreover, it is observed that human BM-MSCs were not recognized by NK cells, as they expressed HLADR molecules (Rasmusson et al., 2003) MSCs exert immunomodulatory effects by inhibiting the complement-mediated effects of peripheral blood mononuclear cell proliferation (Spaggiari et al., 2006; Tu et al., 2010) blocking apoptosis of native and activated neutrophils, as well as reducing the number of neutrophils binding to vascular endothelial cells, limiting the mobilization of these cells to the area of damage (Moll et al., 2011; Cassatella et al., 2011). In response to inflammatory molecules such as interleukin-1 (IL-1), IL-2, IL-12, tumor necrosis factor-a (TNF- $\alpha$ ) and interferon-gamma (INF-y), MSCs secrete an array of growth UniversePG I www.universepg.com factors and anti-inflammatory proteins with complex feedback mechanisms among the many types of immune cells summarize in Table 4 (Munir et al., 2015; Shi et al., 2015; Cagliani et al., 2017; Weiss \& Dahlke, 2019; Maria et al., 2017; Zhao et al., 2016).

The key immunomodulatory cytokines include prostaglandin 2, TGF-b1, HGF, SDF-1, nitrous oxide, indoleamine 2,3-dioxygenase, IL-4, IL-6, IL-10,IL-1 receptor antagonist and soluble tumor necrosis factor-a receptor (Murphy et al., 2013). MSCs prevent proliferation and function of many inflammatory immune cells, including $\mathrm{T}$ cells, natural killer cells, B cells, monocytes, macrophages and dendritic cells. MSCs can block the differentiation of CD34+ cells isolated from the bone marrow or blood monocytes into mature dendritic cells both by direct contact as well as by secreted paracrine factors (Nauta et al., 2006; Jiang et al., 2005). They inhibit the transformation of immature dendritic cells into mature forms and limit the mobilization of dendritic cells to the tissues. (Su et al., 2011) Due to the influence of MSCs, M1 (pro-inflammatory) macrophages are transformed into M2 type cells with an anti-inflammatory phenol-type, and the interleukin (IL)-10 secreted by them inhibits T-cell proliferation (Chen et al., 2014; Gao et al., 2014).

In vitro studies have demonstrated a direct immunemodulatory effect of MSCs on lymphocytes by suppression of activated CD4+ and CD8+ T cells and Blymphocytes was observed (Sharif et al., 2019; Glennie et al., 2005). In addition, MSCs reduce the level of proinflammatory cytokines synthesized by T-lymphocytes, such as tumor necrosis factor (TNF)- $\alpha$ and interferon (IFN)- $\gamma$ (Yañez et al., 2006) and increase synthesis of anti-inflammatory cytokines, for example, IL-4. MSCs also have the ability to limit the synthesis of immuneglobulins like immunoglobulin (Ig) $\mathrm{M}, \mathrm{IgG}$, and $\operatorname{IgA}$ classes secreted by activated B cells, thereby blocking the differentiation of these cells to plasma cells (Corcione et al., 2006). MHC class I chain-like gene A (MICA) together with TLR3 ligand and other immuneregulatory proteins kept the MSCs safe from NKs invasion (Giuliani et al., 2014). Together with other properties, these immunomodulatory features makes MSCs one of the feasible stem-cells sources for performing cell transplantation experiments. 
Table 4: Anti-inflammatory mechanisms of MSCs.

\begin{tabular}{|c|c|c|}
\hline Mechanism & Effects & Target cell \\
\hline PGE2/direct contact & $\begin{array}{c}\downarrow \text { TNF- } \alpha, \text { IL-12, differentiation and activation, Impairs effect on } \\
\text { resting NK cell and } \uparrow I L-23\end{array}$ & Dendritic cells \\
\hline $\begin{array}{l}\text { PGE2, IL-6, IL-8 and } \\
\text { SDF-1 }\end{array}$ & $\uparrow \mathrm{IL}-10$ & Immuture Dendritic cells \\
\hline $\begin{array}{c}\text { PGE2, IDO, HGF, } \\
\text { TGF-b1 and NO } \\
\text { IL-10 } \\
\text { IL-17 } \\
\text { FOXP3-Treg } \\
\text { Gal-1 }\end{array}$ & $\begin{array}{c}\downarrow \mathrm{CD} 4+\mathrm{T} \text {-cell proliferation by S-phase entry block and Go/G1 phase } \\
\text { arrest Inhibits T-cell function, } \downarrow \text { IL-12 } \\
\text { Inactivate TH-1cells } \\
\downarrow \begin{array}{c}\text { TH } 17 \text {-cells proliferation } \\
\uparrow I L-10, \text { IL-13 }\end{array} \\
\text { Antiproliferative effects on activated T cells, supports the survival of } \\
\text { naïve T cells }\end{array}$ & $\begin{array}{l}\text { T cells }(\mathrm{CD} 4+, \\
\text { helper T cells) }\end{array}$ \\
\hline $\begin{array}{l}\text { sHLA-G5 } \\
\text { IL-10, }\end{array}$ & $\begin{array}{c}\downarrow \text { cytotoxicity } \\
\uparrow \text { T-reg production and } \downarrow \text { TH-1, TH-2, TH-17 Cells }\end{array}$ & $\begin{array}{l}\text { T cells }(\mathrm{CD} 8+, \\
\text { cytotoxic T cells) } \\
\text { T-reg cells }\end{array}$ \\
\hline $\begin{array}{c}\text { sHLA-G5 } \\
\text { PGE2, HGF, TGF-b1, } \\
\text { IDO, NO and PD-L1 }\end{array}$ & $\begin{array}{c}\downarrow \text { Treg differentiation } \\
\downarrow \text { Ig antibody production by B cell } \\
\downarrow \text { B-cell proliferation by Go/G1 phase arrest } \\
\downarrow \text { B-cell chemotaxis }\end{array}$ & B cells \\
\hline $\begin{array}{c}\text { PGE2, IDO, sHLA-G5, } \\
\text { HGF, TGF- } \beta 1 \\
\text { IL-15 }\end{array}$ & $\begin{array}{c}\downarrow \mathrm{INF}-\mathrm{y} \text { and IL-2 } \\
\downarrow N K \text { cell proliferation } \\
\downarrow \text { cytotoxicity }\end{array}$ & NK cells \\
\hline PGE2 & $\begin{array}{c}\downarrow \text { Monocyte proliferation by Go/G1 phase arrest } \\
\downarrow \text { Monocyte difference to DC }\end{array}$ & Monocytes \\
\hline $\begin{array}{c}\text { IL-6 } \\
\text { TSG-6 } \\
\text { PGE2, IL-RA, } \\
\text { Phagocytosis }\end{array}$ & $\begin{array}{c}\downarrow \text { TNF- } \alpha \\
\downarrow \text { NF-kB and IL-10 } \\
\text { Converts M1 (pro-inflammatory) type to } \\
\text { M2 (anti-inflammatory) type macrophages }\end{array}$ & Macrophages \\
\hline IL-8, IL-6 & $\begin{array}{c}\downarrow \text { f-MLP- respiratory burst } \\
\downarrow \text { apoptosis }\end{array}$ & Neutrophils \\
\hline $\begin{array}{l}\text { VEGF } \\
\text { IL-1R } \alpha \\
\text { sTNF-R }\end{array}$ & $\begin{array}{c}\text { Pro-angiogenic, Increased nutrient, } \\
\text { O2 and waste transport } \\
\text { Antagonizes IL-1 } \\
\text { Inhibits TNF- } \alpha \text { production }\end{array}$ & No specific target \\
\hline
\end{tabular}

Note: HGF, hepatocyte growth factor; HLA, human leukocyte antigen; IDO, indoleamine 2,3-dioxy-genase; IL-1Ra, IL-1 receptor antagonist; INF, interferon; MMP, matrix metalloproteinase; NF-kB, nuclear factor kappa-light-chain-enhancer of activated B cell; NK, natural killer; NO, nitrous oxide; PD-L1, programmed cell death ligand-1; PGE2, prostaglandin 2; SDF-1, stromal cell-derived factor-1; sTNF-R, soluble TNF-areceptor; TGF, transforming growth factor; TNF, tumor necrosis factor; TSG, tumor necrosis alpha-stimulating gene; VEGF, vascular endothelial growth factor; Gal-1, Galectin-1; FOXP, Forkhead box (FOX) protein; f-MLP, N-formyl-1-methionin-1leucyl-1-phenylalanine.

Furthermore, it is also important to note that MSCs from different sources may differ in their mechanisms and capacities for immune-modulation (Mattar \& Bieback, 2015). Because of their trophic and immunemodulatory functions, MSCs are generally considered to possess greater advantages in cell-based regenerative medicine, MSCs an important regulator of the immune tolerance and attractive therapeutic target for limiting autoimmune inflammation.

\section{CONCLUSION:}

Mesenchymal stem cells have been isolated from a wide range of species and tissues using several tech- niques. MSCs are isolated as a heterogeneous population of cells that differ in growth kinetics and differentiation potentials. A large number of markers have been brought forward to facilitate the isolation of MSCs from their surrounding environment or the selection of MSCs with high stemness. With their ability to differentiate into multiple lineages, secrete factors related to immune regulation, and migrate to-ward sites of inflammation, All these properties of MSCs make them distinct from other stem cells and can be used in future cell replacement therapy and many other clinical implications. In this review, we concisely bring up the current data available for MSCs isolation sources, 
characterization markers and its immunomodulatory properties. The future MSCs research should focus on finding more suitable markers to isolate the sourcespecific MSCs, basic understanding of growth regulators in differentiation and trans-differentiation and its immunomodulatory properties to modify the host immune environment.

\section{ACKNOWLEDGEMENT:}

The authors would like to express their gratitude Pakistan Council of Scientific and Industrial Research for their constructive cooperation throughout the research work.

\section{CONFLICTS OF INTEREST:}

The authors wish to confirm that there are no conflicts of interest associated with this publication and there has been no significant financial support for this work that could have influenced its outcome.

\section{REFERENCES:}

1) An, S. Y.; Han, J.; Park, S. Y. (2014). Valproic acid promotes differentiation of hepatocyte-like cells from whole human umbilical cord-derived mesenchymal stem cells. Tissue Cell. 46(2), 127135. https://doi.org/10.1016/j.tice.2013.12.006

2) Anzalone, R.; Lo Iacono, M.; Corrao, S. (2010). New emerging potentials for human Wharton's jelly mesenchymal stem cells: immunological features and hepatocyte-like differentiative capacity. Stem Cells Dev 19(4), 423-38

https://doi.org/10.1089/scd.2009.0299

3) Baek, H.; Noh, Y. H.; Lee, J. H. (2014). Autonomous isolation, long-term culture and differentiation potential of adult salivary gland-derived stem/progenitor cells. J Tissue Eng Regen Med. 8(9), 717-27. https://doi.org/10.1002/term.1572

4) Baglioni, S.; Squecco, R.; Lombardi, A. (2009). Characterization of human adult stem-cell populations isolated from visceral and subcutaneous adipose tissue. FASEB J. 23(10), 3494-505. https://doi.org/10.1096/fj.08-126946

5) Bartsch, G.; Yoo, J. J.; Siddiqui, M. M. (2005). Propagation, expansion, and multi lineage differentiation of human somatic stem cells from dermal progenitors. Stem Cells Dev. 14(3), 337-48.

6) Barzilay, R.; Melamed, E.; Offen, D. (2009). Lentiviral delivery of LMX1a enhances dopami- nergic phenotype in differentiated human bone marrow mesenchymal stem cells. Stem Cells Dev. 18(4), 591-601.

7) Battula, V. L.; Abele, H.; Bühring, H. J. (2008). Prospective isolation and characterization of mesenchymal stem cells from human placenta using a frizzled-9-specific monoclonal antibody. Differentiation 76(4), 326-36.

https://doi.org/10.1111/j.1432-0436.2007.00225.x

8) Battula, V. L.; Treml, S.; Müller, I. (2009). Isolation of functionally distinct mesenchymal stem cell subsets using antibodies against CD56, CD271, and mesenchymal stem cell antigen-1. Haematologica, 94(2), 173-84.

https://doi.org/10.3324/haematol.13740

9) Bensidhoum, M.; Chapel, A.; Fouillard, L.; (2004). Homing of in vitro expanded Stro-1- or Stro-1+ human mesenchymal stem cells into the NOD/SCID mouse and their role in supporting human CD34 cell engraftment. Blood 103(9), 3313-9.

10) Bhartiya, D. (2013). Are Mesenchymal Cells Indeed Pluripotent Stem Cells or Just Stromal Cells? OCT-4 and VSELs Biology Has Led to Better Understanding. Stem Cells Int 2013: 547501. https://doi.org/10.1155/2013/547501

11) Boxall, S. A.; Jones, E. (2012). Markers for characterization of bone marrow multipotential stromal cells. Stem Cells Int 2012, 975871. https://doi.org/10.1155/2012/975871

12) Cagliani, J.; Grande, D.; Rilo, H. L. R. (2017). Immuno-modulation by Mesenchymal Stromal Cells and their Clinical Applications. J Stem Cell Regen Biol, 3(2).

https://doi.org/10.15436/2471-0598.17.022

13) Cai, J.; Su, H.; Zhu, F. (2010). Generation of human induced pluripotent stem cells from umbilical cord matrix and amniotic membrane mesenchymal cells. J Biol Chem. 285(15), 11227-34.

14) Cassatella, M. A.; Mosna, F.; Lisi, V. (2011). Toll-like receptor-3-activated human mesenchymal stromal cells significantly prolong the survival and function of neutrophils. Stem Cells, 29(6), 1001-11. https://doi.org/10.1002/stem.651

15) Chan, T. M.; Harn, H. J.; Lin, H. P.; Chou, P. W. (2014). Improved human mesenchymal stem cell isolation. Cell Transplant 23(4-5), 399-406. 
16) Chen, P. M.; Liu, K. J.; Yen, B. L. (2014). Induction of immunomodulatory monocytes by human mesenchymal stem cell-derived hepatocyte growth factor through ERK1/2. J Leukoc Biol, 96(2), 295-303.

https://doi.org/10.1189/jlb.3a0513-242r

17) Christodoulou, I.; Kolisis, F. N.; Zoumpourlis, V. (2013). Comparative evaluation of human mesenchymal stem cells of fetal and adult origin during prolonged in vitro expansion: considerations for Cytotherapy. Stem Cells Int 2013, 246134. https://doi.org/10.1155/2013/246134

18) Choi, Y. S.; Dusting, G. J.; Aruno-thayaraj, S. (2010). Differentiation of human adipose-derived stem cells into beating cardiomyocytes. J Cell Mol Med. 14(4), 878-89

https://doi.org/10.1111/j.1582-4934.2010.01009.x

19) Corcione, A.; Benvenuto, F.; Ferretti, E.; Giunti, D. (2006). Human mesenchymal stem cells modulate B-cell functions. Blood, 107(1), 36772. https://doi.org/10.1182/blood-2005-07-2657

20) Covas, D. T.; Panepucci, R. A.; Fontes, A. M. (2008). Multipotent mesenchymal stromal cells obtained from diverse human tissues share functional properties and gene-expression profile with CD146+ perivascular cells and fibroblasts. Exp Hematol 36(5), 642-54.

21) Crisan, M.; Yap, S.; Andriolo, G. (2008). A perivascular origin for mesenchymal stem cells in multiple human organs. Cell Stem Cell. 3(3), 301-13. https://doi.org/10.1016/j.stem.2008.07.003

22) da Silva Meirelles, L.; Malta, T. M.; Covas, D. T. (2015). Cultured Human Adipose Tissue Pericytes and Mesenchymal Stromal Cells Display a Very Similar Gene Expression Profile. Stem Cells Dev, 24(23), 2822-40.

https://doi.org/10.1016/j.gdata.2015.11.009

23) Datta, I.; Mishra, S.; Joshi, P. G. (2011). Neuronal plasticity of human Wharton's jelly mesenchymal stromal cells to the dopaminergic cell type compared with human bone marrow mesenchymal stromal cells. Cytotherapy 13(8), 918-32.

24) Djouad, F.; Bony, C.; Apparailly, F. (2005). Transcriptional profiles discriminate bone marrow- derived and synovium-derived mesenchymal stem cells. Arthritis Res Ther, 7(6), R130415. https://doi.org/10.1186/ar1827
25) Dominici, M.; Le Blanc, K.; Horwitz, E. (2006). Minimal criteria for defining multipotent mesenchymal stromal cells. The International Society for Cellular Therapy position statement. Cytotherapy. 8(4), 315-7

https://doi.org/10.1080/14653240600855905

26) Friedenstein, A. J., Piatetzky-Shapiro, I. I.; Petrakova, K. V. (1966). Osteogenesis in trans-plants of bone marrow cells. J Emb Exp Morphl, 16(3), 381-90. https://doi.org/10.1002/jcp.1040740209

27) Friedenstein, A. J., Chailakhyan, R. K.; Gerasimov, U. V. (1987). Bone marrow osteogenic stem cells: in vitro cultivation and transplantation in diffusion chambers. Cell Tissue Kinet, 20(3), 263-72.

https://doi.org/10.1111/j.1365-2184.1987.tb01309.x

28) Friedenstein, A. J.; Gorskaja, J. F.; Kulagina, N. N. (1976). Fibroblast precursors in normal and irradiated mouse hematopoietic organs. Exp Hematol, 4(5), 267-74.

29) Gabr, M. M.; Refaie, A. F.; Ghoneim, M. A. (2013). Insulin-producing cells from adult human bone marrow mesenchymal stem cells control streptozotocin-induced diabetes in nude mice. Cell Transplant. 22(1), 133-45. https://doi.org/10.1177/0963689718759913

30) Gang, E. J.; Bosnakovski, D.; Figueiredo, C. A.; Visser, J. W.; Perlingeiro, R. C. (2007). SSEA-4 identifies mesenchymal stem cells from bone marrow. Blood 109(4), 174351

31) Gao, S.; Mao, F.; Zhang, B.; Zhang, L. (2014). Mouse bone marrow-derived mesenchymal stem cells induce macrophage M2 polarization through the nuclear factor- $\kappa \mathrm{B}$ and signal transducer and activator of transcription 3 pathways. Exp Biol Med (Maywood), 239 (3), 366-75. https://doi.org/10.1177/1535370213518169

32) Gauthaman, K.; Fong, C. Y.; Bongso, A. (2010). ROCK inhibitor Y-27632 increases thaw-survival rates and pre-serves stemness and differentiation potential of human Wharton's jelly stem cells after cryopreservation. Stem Cell Rev Rep, 6(4), 665-76.

33) Giuliani, M.; Oudrhiri, N.; Lataillade, J. J. (2014). TLR ligands stimulation protects MSC from NK killing. Stem Cells, 32(1), 290-300. https://doi.org/10.1002/stem.1563 
34) Glennie, S.; Lam, E. W.; Dazzi, F. (2005). Bone marrow mesenchymal stem cells induce division arrest energy of activated T cells. Blood, 105(7), 2821-7.

https://pubmed.ncbi.nlm.nih.gov/15591115/

35) Gronthos, S.; Hay, S. J.; Shi, S.; Graves, S. E. (2003). Molecular and cellular characterization of highly purified stromal stem cells derived from human bone marrow. J Cell Sci 116(9), 1827-35. https://doi.org/10.1242/jcs.00369

36) Govindasamy, V.; Ronald, V. S.; Abdullah, A. N.; Ab Aziz, Z. A. (2011). Differentiation of dental pulp stem cells into islet-like aggregates. $J$ Dent Res. 90(5), 646-52.

37) Hang, H.; Yu, Y.; Huang, Q. (2014). Induction of highly functional hepatocytes from human umbilical cord mesenchymal stem cells by HNF4 $\alpha$ transduction. PLoS One. 9(8), e104133. https://doi.org/10.1371/journal.pone.0104133. eCol lection 2014

38) Hatakeyama, A.; Uchida, S.; Utsunomiya, H. (2017). Isolation and Characterization of Synovial Mesenchymal Stem Cell Derived from Hip Joints: A Comparative Analysis with a Matched Control Knee Group. Stem Cells Int 2017, 9312329.

39) Hilkens, P.; Gervois, P.; Fanton, Y. (2013). Effect of isolation methodology on stem cell properties and multiline age differentiation potential of human dental pulp stem cells. Cell Tissue Res. 353(1), 65-78.

https://doi.org/10.1007/s00441-013-1630-X

40) Hou, T.; Xu, J.; Wu, X. (2009). Umbilical cord Wharton's Jelly: a new potential cell source of mesenchymal stromal cells for bone tissue engineering. Tissue Eng Part: A 15(9), 2325-34.

41) Huang, G. T.; Gronthos, S.; Shi, S. (2009). Mesenchymal stem cells derived from dental tissues vs. those from other sources: their biology and role in regenerative medicine. $J$ Dent Res. 88(9), 792-806.

https://doi.org/10.1177/0022034509340867

42) Huang, S. J.; Fu, R. H.; Liu, S. (2013). Adiposederived stem cells: isolation, characterization, and differentiation potential. Cell Transplant 22(4), 701-9.

https://pubmed.ncbi.nlm.nih.gov/23068312/
43) In't Anker, P. S.; Scherjon, S. A.; Kleijburg-van der Keur, C. (2003). Amniotic fluid as a novel source of mesenchymal stem cells for therapeutic transplantation. Blood. 102(4), 1548-9

44) Jankowski, R. J.; Deasy, B. M.; Huard, J. (2002) Muscle-derived stem cells. Gene Ther, 9(10), 642-7. https://doi.org/10.1038/sj.gt.3301719

45) Jiang, X. X.; Zhang, Y.; Mao, N. (2005). Human mesenchymal stem cells inhibit differentiation and function of monocyte-derived dendritic cells. Blood, 105(10), 4120-6.

46) Jiao, F.; Wang, J.; Wang, X. (2012). Human mesenchymal stem cells derived from limb bud can differentiate into all three embryonic germ layers lineages. Cell Reprogram. 14(4), 324-33. https://doi.org/10.1089/cell.2012.0004

47) Johnstone, B.; Hering, T. M.; Yoo, J. U. (1998). In vitro chondrogenesis of bone marrow-derived mesenchymal progenitor cells. Exp Cell Res, 238(1), 265-72.

48) Kanafi, M. M.; Gupta, S.; Bhonde, R. R. (2013). Transplantation of islet-like cell clusters derived from human dental pulp stem cells restores normoglycemia in diabetic mice. Cytotherapy. 15(10), 1228-36.

https://doi.org/10.1016/j.jcyt.2013.05.008

49) Kang, S. K.; Lee, D. H.; Jung, J. S. (2003). Improvment of neurological deficits by intracerebral transplantation of human adipose tissuederived stromal cells after cerebral ischemia in rats. Exp Neurol 183(2), 355-66.

https://pubmed.ncbi.nlm.nih.gov/14552877/

50) Karystinou, A.; Kurth, T. B.; Wackerhage, H. (2009). Distinct mesenchymal progenitor cell subsets in the adult human synovium. Rheumatology (Oxford) 48(9), 1057-64.

51) Kim, N.; Cho, S. G., (2013). Clinical applications of mesenchymal stem cells. Korean J Intern Med 28(4), 387-402. https://doi.org/10.3904/kjim.2013.28.4.387

52) Kuroda, Y.; Kitada, M.; Wakao, S. (2010). Unique multi-potent cells in adult human mesenchymal cell populations. Proc Natl Acad Sci, USA 107(19), 8639-43.

53) La Rocca, G.; Loria, T.; Lo M. (2009). Isolation and characterization of Oct-4+/HLA-G+ mesenchymal stem cells from human umbilical cord 
matrix: differentiation potential and detection of new markers. Hist Cell Biol. 131(2), 267-82.

https://doi.org/10.3727/096368915X686841

54) Li, H.; Zacharaki, D.; Lim, H. C.; Scheding, S. (2016). Isolation and characterization of primary bone marrow mesenchymal stromal cells. Ann $N$ Y Acad Sci. 1370(1), 109-18.

55) Lin, C. S.; Lin, G.; Lue, T. F. (2012). Is CD34 truly a negative marker for mesenchymal stromal cells? Cytotherapy, 14(10), 1159-63.

https://doi.org/10.3109/14653249.2012.729817

56) Lv, F. J.; Tuan, R. S.; Cheung, K. M.; Leung, V. Y. (2014). Concise review: the surface markers and identity of human mesenchymal stem cells. Stem Cells, 32(6), 1408-19.

57) Mabuchi, Y.; Harada, S.; Niibe, K. (2013). LNGFR(+)THY-1(+)VCAM-1(hi+) cells reveal functionally distinct subpopulations in mesenchymal stem cells. Stem Cell Reports, 1(2), 15265. https://doi.org/10.1007/s12185-015-1921-y

58) Maijenburg, M. W.; Kleijer, M.; Voermans, C. (2012). The composition of the mesenchymal stromal cell compartment in human bone marrow changes during development and aging. Haematologica, 97 (2), 179-83.

59) Mamidi, M. K.; Singh, G.; Thrichelvam, S. T. (2012). Comparative cellular and molecular analyses of pooled bone marrow multipotent mesenchymal stromal cells during continuous passaging and after successive cryopreservation. J Cell Biochem. 113(10), 3153-64.

https://doi.org/10.1002/jcb.24193

60) Maria, A. T.; Noël, D.; Guilpain, P. (2017). Adipose-Derived Mesenchymal Stem Cells in Autoimmune Disorders: State of the Art and Perspectives for Systemic Sclerosis. Clin Rev Allergy Immunol 52(2), 234-259.

61) Masuda, H.; Rao, J. R.; Gargett, C. E. (2012). A novel marker of human endometrial mesenchymal stem-like cells. Cell Trans, 21(10), 220114. https://doi.org/10.3727/096368911X637362

62) Mattar, P.; Bieback, K. (2015). Comparing the immunomodulatory properties of bone marrow, adipose tissue, and birth-associated tissue mesenchymal stromal cells. Front Immunol, 6, 560.

63) Miao, Z.; Jin, J.; Zhang, X. (2006). Isolation of mesenchymal stem cells from human placenta: comparison with human bone marrow mesenchymal stem cells. Cell Biol Int. 30(9), 681-7. https://doi.org/10.1016/j.cellbi.2006.03.009

64) Moll, G.; Jitschin, R.; Sundberg, B. (2011). Mesenchymal stromal cells engage complement and complement receptor bearing innate effector cells to modulate immune responses. PLoS One, 6(7), e21703. https://pubmed.ncbi.nlm.nih.gov/21747949/

65) Morito, T.; Hara, K.; Ju, Y. J.; Umezawa, A. (2008). Synovial fluid-derived mesenchymal stem cells increase after intra-articular ligament injury in humans. Rheumatology, 47(8), 1137-43. https://doi.org/10.1093/rheumatology/ken114

66) Munir, H.; Nash, G. B.; McGettrick, H. (2015). Analyzing the effects of stromal cells on the recruitment of leukocytes from flow. $J$ Vis Exp, (95), e52480.

67) Murphy, M. B.; Moncivais, K.; Caplan, A. I. (2013). Mesenchymal stem cells: environmentally responsive therapeutics for regenerative medicine. Exp Mol Med, 45, e54.

https://doi.org/10.1038/emm.2013.94

68) Mushahary, D.; Spittler, A.; Kasper, C. (2018). Isolation, cultivation, and characterization of human mesenchymal stem cells. Cytometry A. 93(1), 19-31.

69) Nauta, A. J.; Lurvink, E.; Fibbe, W. E. (2006). Mesenchymal stem cells inhibit generation and function of both CD34+-derived and monocytederived dendritic cells. J Immunol, 177 (4), 20807. https://doi.org/10.4049/jimmunol.177.4.2080

70) Orciani, M.; Morabito, C.; Di Primio, R. (2010). Functional characterization of calcium-signaling pathways of human skin-derived mesenchymal stem cells. Skin Pharma. Physiol, 23(3), 124-32. https://pubmed.ncbi.nlm.nih.gov/20051713/

71) Otsuru, S.; Olson, T. S.; Horwitz, E. M. (2013). Improved isolation and expansion of bone marrow mesenhymal stromal cells using a novel marrow filter device. Cytotherapy. 15(2), 146-53. https://doi.org/10.1016/j.jcyt.2012.10.012

72) Pachón-Peña, G.; Yu, G.; Gimble, J. M. (2011). Stromal stem cells from adipose tissue and bone marrow of age-matched female donors display distinct immunophenotypic profiles. $J$ Cell Physiol, 226 (3), 843-51.

https://doi.org/10.1002/jcp.22408 
73) Paduano, F.; Marrelli, M.; Palmieri, F. (2016). CD146 Expression Influences Periapical Cyst Mesenchymal Stem Cell Properties. Stem Cell Rev Rep, 12(5), 592-603. https://pubmed.ncbi.nlm.nih.gov/27406247/

74) Pendleton, C.; Li, Q.; Yuan, K. (2013). Mesenchymal stem cells derived from adipose tissue vs bone marrow: in vitro comparison of their tropism towards gliomas. PLoS One. 8(3), e58198. https://doi.org/10.1371/journal.pone.0058198

75) Pérez-Silos, V.; Camacho-Morales, A.; FuentesMera, L. (2016). Mesenchymal Stem Cells Subpopulations: Application for Orthopedic Regenerative Medicine. Stem Cells Int 2016, 3187491.

76) Phadnis, S. M.; Nair, P. D.; Hardikar, A. A. (2011). Human bone marrow-derived mesenchymal cells differentiate and mature into endocrine pancreatic lineage in vivo. Cytotherapy. 13(3), 279-93.

https://doi.org/10.3109/14653249.2010.523108

77) Pilbauerová, N.; Suchánek, J., Soukup, T. (2019). Enzymatic Isolation, Amplification and Characterization of Dental Pulp Stem Cells. Folia Biol (Praha), 65(3), 124-133.

78) Pittenger, M. F.; Beck, S. C.; Mosca, J. D. (1999). Multi lineage potential of adult human mesenchymal stem cells. Science 284(5411), 1437. https://doi.org/10.1126/science.284.5411.143

79) Prabakar, K. R.; Pileggi, A.; Inverardi, L. (2012). Generation of glucose-responsive, insulin-producing cells from human umbilical cord bloodderived mesenchymal stem cells. Cell Transplant 21(6), 1321-39.

https://pubmed.ncbi.nlm.nih.gov/22195604/

80) Psaltis, P. J.; Paton, S.; See, F.; Martin, S. (2010). Enrichment for STRO-1 expression enhances the cardiovascular paracrine activity of human bone marrow-derived mesenchymal cell populations. $J$ Cell Physiol 223(2), 530-40.

https://doi.org/10.1002/jcp.22081

81) Quirici, N.; Scavullo, C.; de Girolamo, L. (2010). Anti-L-NGFR and -CD34 monoclonal antibodies identify multipotent mesenchymal stem cells in human adipose tissue. Stem Cells Dev, 19(6), 915-25.

82) Qu-Petersen, Z; Deasy, B.; Ikezawa, M. (2002). Identification of a novel population of muscle stem cells in mice: potential for muscle regeneration. J Cell Biol, 157(5), 851-64.

https://doi.org/10.1083/jcb.200108150

83) Ranera, B.; Remacha, A. R.; Álvarez-Arguedas, S. (2013). Expansion under hypoxic conditions enhances the chondrogenic potential of equine bone marrow-derived mesenchymal stem cells. Vet J. 195(2), 248-51.

84) Rasmusson, I.; Ringdén, O.; Le Blanc, K. (2003). Mesenchymal stem cells inhibit the formation of cytotoxic $\mathrm{T}$ lymphocytes, but not activated cytotoxic T lymphocytes or natural killer cells. Transplantation, 76(8), 1208-13.

https://doi.org/10.1097/01.tp.0000082540.43730.80

85) Raynaud, C. M.; Lis, R.; Rafii, A. (2012). Comprehensive characterization of mesenchymal stem cells from human placenta and fetal membrane and their response to osteoactivin stimulation. Stem Cells Int. 2012, 658356.

86) Riekstina, U.; Muiznieks, I.; Ancans, J. (2008). Characterization of human skin-derived mesenchymal stem cell proliferation rate in different growth conditions. Cytotechnology. 58(3), 15362. https://doi.org/10.1007/s10616-009-9183-2

87) Rotter, N.; Oder, J.; Rohwedel, J. (2008). Isolation and characterization of adult stem cells from human salivary glands. Stem Cells Dev. 17(3), 509-18.

88) Sacchetti, B.; Funari, A.; Saggio, I. (2007). Selfrenewing osteoprogenitors in bone marrow sinusoids can organize a hematopoietic microenvironment. Cell 131(2), 324-36. https://doi.org/10.1016/j.cell.2007.08.025

89) Saeedi, P.; Halabian, R.; Imani Fooladi, A. A. (2019). A revealing review of mesenchymal stem cells therapy, clinical perspectives and Modification strategies. Stem Cell Investig 6, 34.

90) Safford, K. M.; Hicok, K. C.; Safford, S. D. (2002). Neurogenic differentiation of murine and human adipose-derived stromal cells. Biochem Biophys Res Commun. 294(2), 371-9 https://doi.org/10.1016/s0006-291x(02)00469-2

91) Salehinejad, P.; Ali, A. M.; Omar, A. R. (2012). Comparison of different methods for the isolation of mesenchymal stem cells from human umbilical cord Wharton's jelly. In Vitro Cell Dev Biol Anim 48(2), 75-83. 
92) Sato, A.; Okumura, K.; Endo, F. (2007). Isolation, tissue localization, and cellular characterization of progenitors derived from adult human salivary glands. Cloning Stem Cells. 9(2), 191-205. https://doi.org/10.1089/clo.2006.0054

93) Schwab, K. E.; Gargett, C. E. (2007). Co-expression of two perivascular cell markers isolates mesenchymal stem-like cells from human endometrium. Hum Reprod, 22(11), 2903-11.

94) Sharif IH, Mosaib MG, and Uddin ME. (2019). Assessment and biomonitoring of the effect of rapeseeds oil on wister rat organs. Am. J. Pure Appl. Sci., 1(4), 20-29. https://doi.org/10.34104/ajpab.019.0192029

95) Shi, Q.; Yin, Z.; Wang, S. (2015). PGE2 Elevates IL-23 Production in Human Dendritic Cells via a cAMP Dependent Pathway. Medi. Inflam, 2015, 984690. https://doi.org/10.1155/2015/984690

96) Simmons, P. J.; Torok-Storb, B. (1991). Identification of stromal cell precursors in human bone marrow by a novel monoclonal antibody, STRO1. Blood, 78(1), 55-62.

97) Spaggiari, G. M.; Becchetti, S.; Moretta, L. (2006). Mesenchymal stem cell-natural killer cell interactions: evidence that activated NK cells are capable of killing MSCs, whereas MSCs can inhibit IL-2-induced NK-cell proliferation. Blood, 107(4), 1484-90. https://doi.org/10.1182/blood-2005-07-2775

98) Stock, P.; Dollinger, M. M.; Christ, B. (2014). Human bone marrow mesenchymal stem cellderived hepatocytes improve the mouse liver after acute acetaminophen intoxication by preventing progress of injury. Int J Mol Sci. 15(4), 7004-28

99) Su, W. R.; Shi, S. H.; Le, A. D. (2011). Human gingiva-derived mesenchymal stromal cells attenuate contact hypersensitivity via prostaglandin E2-dependent mechanisms. Stem Cells, 29(11), 1849-60. https://doi.org/10.1002/stem.738

100) Sui, Y.; Li, Y.; Hu, W. (2020) Generation of functional salivary gland tissue from human submandibular gland stem/progenitor cells. Stem Cell Res Ther, 11(1), 127.

101) Tang, D. Q.; Wang, Q.; Yang, L. J. (2012). In vitro generation of functional insulin-producing cells from human bone marrow-derived stem cells, but long-term culture running risk of malignant transformation. Am J Stem Cells. 1(2), 114-127.

https://www.ncbi.nlm.nih.gov/pmc/articles/PMC34 $\underline{02040 /}$

102) Thomson, J. A., Shapiro, S. S.; Jones, J. M. (1998). Embryonic stem cell lines derived from human blastocysts. Science, 282(5391), 1145-7.

103) Timper, K.; Müller, B.; Zulewski, H. (2006). Human adipose tissue-derived mesenchymal stem cells differentiate into insulin, somatostatin, and glucagon expressing cells. Biochem Biophys Res Commun. 341(4), 1135-40. https://doi.org/10.1016/j.bbrc.2006.01.072

104) Tormin, A.; Li, O.; Walsh, S. (2011). CD146 expression on primary non-hematopoietic bone marrow stem cells is correlated with in situ localization. Blood, 117(19), 5067-77.

105) Tosh, D.; Strain, A. (2005). Liver stem cells-prospects for clinical use. J Hepatol, 42(1), S7584. https://doi.org/10.1016/j.jhep.2004.12.009

106) Tsai, M. S.; Lee, J. L.; Hwang, S. M. (2004). Isolation of human multipotent mesenchymal stem cells from second-trimester amniotic fluid using a novel two-stage culture protocol. Hum Reprod. 19(6), 1450-6.

107) Tuli, R.; Tuli, S.; Wang, M. L. (2003). Characterization of multipotential mesenchymal progenitor cells derived from human trabecular bone. Stem Cells, 21(6), 681-93. https://doi.org/10.1634/stemcells.21-6-681

108) Tu, Z.; Li, Q.; Lin, F. (2010). Mesenchymal stem cells inhibit complement activation by secreting factor H. Stem Cells Dev 19(11), 1803-9.

109) Ullah, I.; Subbarao, R. B.; Rho, G. J. (2015). Human mesenchymal stem cells - current trends and future prospective. Biosci Rep. 35(2).

110) Vaculik, C.; Bauer, W.; Iram, N. (2012). Human dermis harbors distinct mesenchymal stromal cell subsets. J Invest Dermatol 132(1), 563-74. https://doi.org/10.1038/jid.2011.355

111) Vasiliki, E. K. (2016). Mesenchymal Stem Cells Markers. Open Access J Neurol Neuro-surgery 1(3); 555561.

112) Vishnubalaji, R.; Manikandan, M.; Al-Nbaheen, M. (2012). In vitro differentiation of human skin-derived multipotent stromal cells into 
putative endothelial-like cells. BMC Dev Biol 12,

7. https://doi.org/10.1186/1471-213X-12-7

113) Völlner, F.; Ernst, W.; Driemel, O. (2009). A two-step strategy for neuronal differentiation in vitro of human dental follicle cells. Differentiation. 77(5), 433-41.

https://pubmed.ncbi.nlm.nih.gov/19394129/

114) Wagner, W.; Wein, F.; Frank-hauser, M. (2005). Comparative characteristics of mesenchymal stem cells from human bone marrow, adipose tissue, and umbilical cord blood. Exp Hematol. 33(11), 1402-16.

https://doi.org/10.1016/j.exphem.2005.07.003

115) Wang, J.; Shi, S.; Wang, S. (2010). Stem cells from human-exfoliated deciduous teeth can differentiate into dopaminergic neuron-like cells. Stem Cells Dev. 19(9), 1375-83. https://doi.org/10.1089/scd.2009.0258

116) Wang, Y.; Wang, F.; Chen, H.; Zhang, K. (2014). Human adipose-derived mesenchymal stem cells are resistant to HBV infection during differentiation into hepatocytes in vitro. Int $\mathrm{J} \mathrm{Mol}$ Sci. 15(4), 6096-110.

117) Weiss, A. R. R.; Dahlke, M. H. (2019). Immunomodulation by Mesenchymal Stem Cells (MSCs): Mechanisms of Action of Living, Apoptotic, and Dead MSCs. Front Immunol 10, 1191. https://doi.org/10.3389/fimmu.2019.01191

118) Wilkins, A.; Ginty, M.; Hares, K.; Scolding, N. (2009). Human bone marrow-derived mesenchymal stem cells secrete brain-derived neurotrophic factor which promotes neuronal survival in vitro. Stem Cell Res. 3(1), 63-70.

119) Xu, W.; Zhu, W.; Sun, X. (2004). Mesenchymal stem cells from adult human bone marrow differentiate into a cardio-myocyte phenotype in vitro. Exp Biol Med. 229(7), 623-31. https://doi.org/10.1177/153537020422900706
120) Yañez, R.; Lamana, M. L.; García-Castro, J. (2006). Adipose tissue-derived mesenchymal stem cells have in vivo immunosuppressive properties applicable for the control of the graftversus-host disease. Stem Cells, 24 (11), 2582-91.

121) Yazdekhasti; H, H. J., Rajabi Z, Aliakbari F. (2018). Germline cells derived from mesenchymal stem cells, with the focus on Wharton's jelly. Asian Pacific J. of Reproduction, 7(2), 49-55. https://doi.org/10.4103/2305-0500.228013

122) Yoon, J. H.; Shin, S.; Jung, N. H. (2013). Comparison of explants derived and enzymatic digestion-derived MSCs and the growth factors from Wharton's jelly. Biomed Res Int 2013, 428726.

123) Zhang, X.; Hirai, M.; Igura, K.; Satoh, (2011). Isolation and characterization of mesenchymal stem cells from human umbilical cord blood: reevaluation of critical factors for successful isolation and high ability to proliferate and differentiate to chondrocytes as compared to mesenchymal stem cells from bone marrow and adipose tissue. J Cell Biochem. 112 (4), 1206-18. https://doi.org/10.1002/jcb.23042

124) Zhao, F.; Qu, Y.; Mu, D. (2014). Umbilical cord blood mesenchymal stem cells co-modified by TERT and BDNF: a novel neuroprotective therapy for neonatal hypoxic-ischemic brain damage. Int J Dev Neurosci. 38, 147-54. https://doi.org/10.1016/j.bbr.2019.01.012

125) Zhao, Q.; Ren, H., Han, Z. (2016). Mesenchymal stem cells: Immunomodulatory capability and clinical potential in immune diseases. Journal of Cellular Immunotherapy, 2(1), 3-20.

126) Zuk, P. A., (2010).The adipose-derived stem cell: looking back and looking ahead. Mol Biol Cell, 21(11), 1783-7. https://doi.org/10.1091/mbc.E09-07-0589

Citation: Abbasi K, Iqbal S, Bano S, Siddiqui K, and Muthiah L. (2021). More to explore; the mesenchymal stem cells (MSCs) major tissue sources, known surface markers and its immunomodulation properties. Am. J. Pure Appl. Sci., 3(4), 85-97. https://doi.org/10.34104/ajpab.021.085097 @) @ 